\title{
Scour depth around multiple piles for current and wave
}

\author{
Hyoseob Kim ${ }^{1}$, Byoungwook Min ${ }^{2}$, Hee-Suk Ryoo ${ }^{3}$ \\ ${ }^{1,2}$ Kookmin University, Seoul, Korea \\ ${ }^{3}$ Korea Electrotechnology Research Institute, Gyeongsangnam-do, Korea \\ ${ }^{2}$ Corresponding author

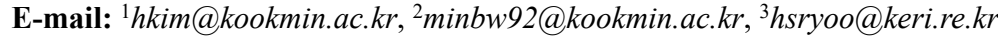 \\ Received 16 August 2018; accepted 24 August 2018 \\ DOI https://doi.org/10.21595/vp.2018.20164
}

Check for updates

Copyright (C) 2018 Hyoseob Kim, et al. This is an open access article distributed under the Creative Commons Attribution License, which permits unrestricted use, distribution, and reproduction in any medium, provided the original work is properly cited.

\begin{abstract}
Experiments on scour around multiple piles were carried out for several current and wave conditions: pile numbers were 1, 3, and 7; and wave only, current only, and current and wave flows. A moderate wave condition was chosen as the representative wave, which produced relatively small scour depth. A depth-average current speed was chosen as the representative current, which produced relatively large scour hole. When waves were superimposed on current, scour hole depth decreased. Existing the Sumer and Fredsøe's prediction formula of scour hole depth for current and wave flows for multiple piles describes the present experimental results reasonably well.
\end{abstract}

Keywords: scour, group piles, experiment, scour depth, wave, current.

\section{Introduction}

Scour around vertical structures can cause several engineering problems, e. g. reducing bearing capacity of the structure, or increasing tensions of relevant pipelines or cables attached to the structure. Prediction of scour focuses on either final equilibrium state, or time-evolving feature. For instance, the scour starts to develop when the structure is constructed until reaches equilibrium. Scour could keep on changing, if the surrounding flows change continuously like tidal flow.

Equilibrium scour hole depth around vertical cylindrical structures for steady flow has been extensively studied through laboratory experiments or numerical experiments, and empirical formulas for prediction have been proposed by many researchers. In study of Sumer and Fredsøe [1], the Keulegan-Carpenter number has proven to be the dominant variable deciding the equilibrium scour depth. Sumer et al. [2] studied scour around vertical pile in wave. In that study, the results of an experimental measuring on scour around piles were presented. Also based on their data, a design equation was established, relating the scour depth to the Keulegan-Carpenter number. When multiple piles are constructed, scour hole depths are affected by the number of the piles as well as the dimensions of the mono pile due to enhanced turbulence generated by many piles. The additional influence of scour depth has been accounted by the ratio between the gap width and the pile diameter (Sumer and Fredsøe [3]). However, it is presumed that the above ratio of the gap width over the pile diameter may not be sufficient for prediction of the overall scour hole depth. The number of piles or the total area of the multiple piles may influence the group-related scour depth, $s_{g} . s_{g}$ is the group-related scour depth, and $s_{l}$ is the local scour depth, see Fig. 1.

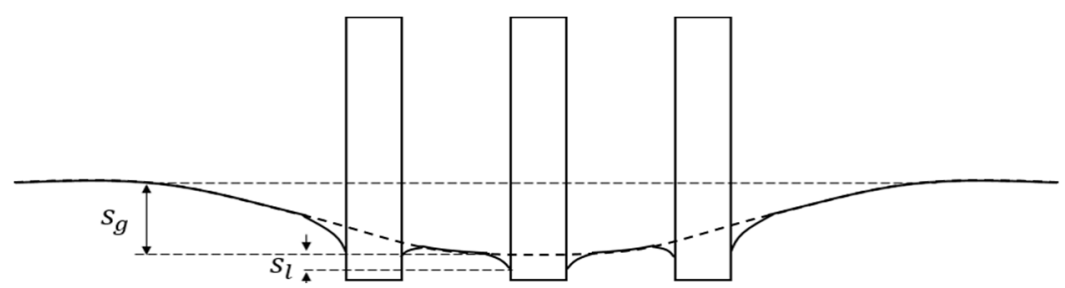

Fig. 1. Scour depth group-related and local scour depth 
It may be meaningful to investigate the effect of the number of piles with the same ratio of the gap over the pile diameter, while keeping all the other parameters identical.

\section{Experiment design}

In order to distinguish the effect of multiplicity of piles explicitly, experimental cases were carefully designed for the present study. We intend to extract the effect of pile numbers, while keeping all the other variables steady.

Typical three flow conditions were chosen as representative flow environments: wave only, current only, and current and wave coexisting flows. It could be expected that these cases may not cover wide range of flow situation, but reveal the characteristics of the scour with multiple piles.

The two-dimensional flume at Kookmin University, Seoul, Korea was used: $0.8 \mathrm{~m}$ wide, 1.0 deep, and $23 \mathrm{~m}$ long. The flume includes panel-type wave generator, and reversible current generating pump, see Fig. 2.

The water depth was maintained $0.5 \mathrm{~m}$ at centre of sandy bed, and the circular vertical pile diameter was $10 \mathrm{~cm}$. the gap width ratio for both 3 and 7 piles were 2, see Fig. 3 .

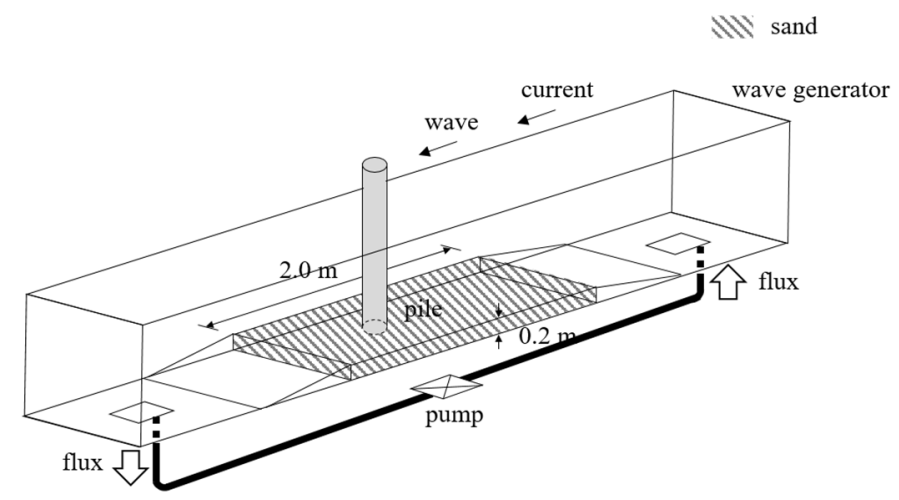

Fig. 2. Experimental model and current and wave direction

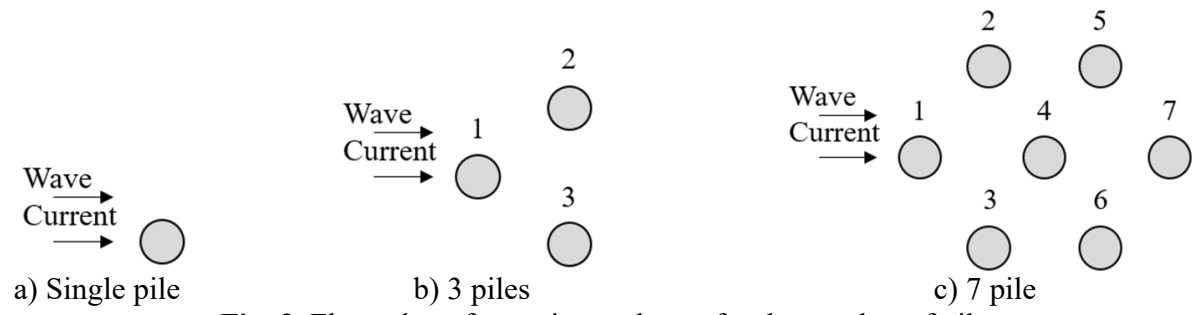

Fig. 3. Floor plan of experimental case for the number of piles

Bed material should be chosen to represent field conditions. Considering west coast of Korea, where bed material is mainly sand along main tidal channels, and mixed sand and silt around shaded zones. Median sand diameter is between 100-300 $\mu \mathrm{m}$ on the west coast of Korea. Applying the length scale of model over prototype of 1/40, and Froude similarity, could be applied to the settling velocity. Then, the adequate sand median diameter should be $80 \mu \mathrm{m}$, which was used for the present experiments.

The sandy bed was prepared within $2.0 \mathrm{~m}$ length between two transitional steps, see Fig. 2 . The sand depth was $20 \mathrm{~cm}$, which may be sufficiently deep for possible scour due to waves and currents.

In order to distinguish the effect of the total pile number on the total scour depth, a typical wave condition needs to be chosen, so that it is applied to most experimental cases.

In study of Sumer and Fredsøe [1], the Keulegan-Carpenter number has proven to be the 
variable dominating the equilibrium scour depth:

$K C=\frac{U_{m} T}{D}$

where $U_{m}$ is the undisturbed linear near-bed orbital velocity amplitude, $T$ is the wave period, and $D$ is the pile diameter.

Keulegan-Carpenter number is known as a dimensionless quantity describing the relative importance of the drag forces over inertia forces for bluff objects in an oscillatory fluid flow.

We choose a monochromatic wave train of period $1.5 \mathrm{~s}$, and $10 \mathrm{~cm}$ amplitude on the water depth of $0.5 \mathrm{~m}$, which results in $\mathrm{KC}$ of 2.5, which implies waves are large to produce scour around piles. The fact that the $\mathrm{KC}$ number does not reflect information on the bed material like median bed size, implies that the scour hole depths are strongly controlled by the structural dimension, if the flow speed is above a threshold value.

Preliminary experiments demonstrate bedform existence for a range of current speeds. Depth-average current velocity of $50 \mathrm{~cm} / \mathrm{s}$ produces large bed shear stress, and consequent scour holes. Depth-average current velocity was kept on $0.5 \mathrm{~cm} / \mathrm{s}$ by adjusting the flow rate meter, for current only cases and current and wave cases.

The experimental cases were designed as combinations of 3 flow cases and 3 pile alignments cases, i.e. current, wave, current/wave flows, multiplied by single, 3 , and 7 piles cases; i.e. 9 cases altogether.

\section{Results}

The experiment results of the scour depths are shown in the following tables.

Table 1. Measured scour depth for single pile

\begin{tabular}{|c|c|c|}
\hline Case number & Condition & Scour depth $(\mathrm{cm})$ \\
\hline 1 & Current only & 7.2 \\
\hline 2 & Wave only & 0.3 \\
\hline 3 & Current and Wave & 6.9 \\
\hline
\end{tabular}

Table 2. Measured scour depth for 3 group piles

\begin{tabular}{|c|c|c|c|}
\hline Case number & Condition & Pile & Scour depth $(\mathrm{cm})$ \\
\hline \multirow{4}{*}{4} & \multirow{4}{*}{ Current only } & 1 & 8.5 \\
\hline & & 2 & 9.6 \\
\hline & & 3 & 10.3 \\
\hline & & Average & 9.5 \\
\hline \multirow{4}{*}{5} & \multirow{4}{*}{ Wave only } & 1 & 1.7 \\
\hline & & 2 & 1.9 \\
\hline & & 3 & 0.9 \\
\hline & & Average & 1.5 \\
\hline \multirow{4}{*}{6} & \multirow{4}{*}{ Current and Wave } & 1 & 7.3 \\
\hline & & 2 & 8.7 \\
\hline & & 3 & 8.9 \\
\hline & & Average & 8.3 \\
\hline
\end{tabular}

First, the scour depth of Case 1 for current only and single pile was $7.2 \mathrm{~cm}$, which is 0.72 times the pile diameter.

The scour depth of Case 2 for wave only and single pile was $0.3 \mathrm{~cm}$, which is much smaller than that of current only case (Case 1). The wave orbital velocity near bed is $17.7 \mathrm{~cm} / \mathrm{s}$, and is thought to be comparable with the depth-average current speed of $0.5 \mathrm{~m} / \mathrm{s}$. small scour depth for their case could be understood as periodically reversing flow behaviors. 
Table 3. Measured scour depth for 7 group piles

\begin{tabular}{|c|c|c|c|}
\hline Case number & Condition & Pile & Scour depth $(\mathrm{cm})$ \\
\hline \multirow{8}{*}{7} & \multirow{8}{*}{ Current only } & 1 & 11.9 \\
\hline & & 2 & 12.2 \\
\hline & & 3 & 10.7 \\
\hline & & 4 & 12.8 \\
\hline & & 5 & 11.9 \\
\hline & & 6 & 13.3 \\
\hline & & 7 & 13.2 \\
\hline & & Average & 12.3 \\
\hline \multirow{8}{*}{8} & \multirow{8}{*}{ Wave only } & 1 & 2.5 \\
\hline & & 2 & 2 \\
\hline & & 3 & 1.9 \\
\hline & & 4 & 2.4 \\
\hline & & 5 & 2.7 \\
\hline & & 6 & 2.3 \\
\hline & & 7 & 2.2 \\
\hline & & Average & 2.3 \\
\hline \multirow{8}{*}{9} & \multirow{8}{*}{ Current and Wave } & 1 & 11.7 \\
\hline & & 2 & 11.9 \\
\hline & & 3 & 9.4 \\
\hline & & 4 & 12.5 \\
\hline & & 5 & 12.4 \\
\hline & & 6 & 12.9 \\
\hline & & 7 & 12.8 \\
\hline & & Average & 11.9 \\
\hline
\end{tabular}

The scour depth of Case 3 for current and wave flow and single pile was $6.9 \mathrm{~cm}$, which is slightly smaller than that of for current only case. It is thought that the instantaneous friction bed shear stress around scour hole may exceed a limiting value dividing the normal flow and sheet flow.

The scour depth of Case 4 current only flow and 3 piles was $9.5 \mathrm{~cm}$ on average, larger than those for single pile case, Case 1. The scour depth of Case 7, current only flow and 7 piles was $12.3 \mathrm{~cm}$ on average, larger than those for single pile case, and 3 piles case.

The scour depth of Case 5 wave only and 3 piles was $1.5 \mathrm{~cm}$ on average, larger than those for single pile case, Case 1 . The scour depth of Case 8 wave only and 7 piles was $2.3 \mathrm{~cm}$ on average, larger than those for single pile case, and 3 piles case.

The scour depth of Case 6 current and wave and 3 piles was $8.3 \mathrm{~cm}$ on average, larger than those for single pile case, Case 3. The scour depth of Case 9 current and wave and 7piles was $11.9 \mathrm{~cm}$ average, larger than those for single pile case and 3 piles case, see Figs. 4-6.

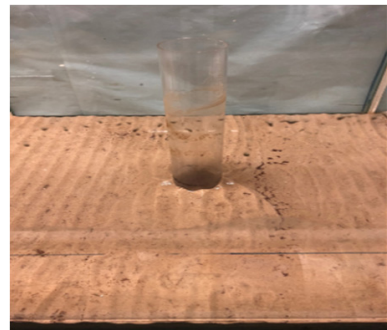

a) Wave

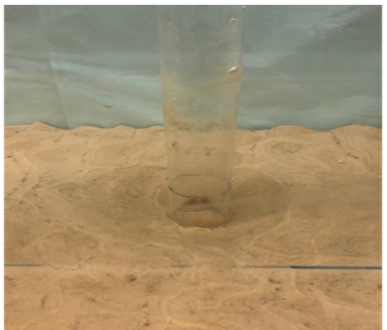

b) Current

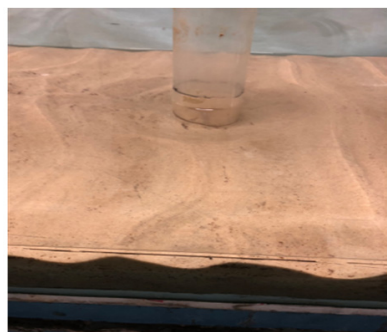

c) Current and wave

Fig. 4. Photo of single pile experiment result

This paper in case of group pile, the scour depth for each pile was averaged and compared. 
Sumer et al. [2] and Sumer and Fredsøe's parameter [4] used for compared experimental scour depth with the theoretical scour depth.

Sumer et al. [2]:

$\frac{S}{D}=1.3[1-\exp (-0.03(K C-6))], \quad K C \geq 6$.

In case of current and wave case, the scour depth is a function of the $K C$ number and the parameter $U_{c w}=U_{c} /\left(U_{c}+U_{m}\right)$. Sumer and Fredsøe introduced $U_{c w}$ defined as:

Sumer and Fredsøe's parameter $U_{c w}[4]$ :

$U_{c w}=\frac{U_{c}}{U_{c}+U_{m}}$,

where $U_{m}$ is the maximum value of orbital velocity of water particles at bed, and $U_{c}$ is the current velocity at distance of $\mathrm{D} / 2$ from bed.

For comparison, the scour depth was non-dimensionalized by $S / D$. Compare Sumer and Fredsøe formula with experimental result. The results are as follows, see Fig. 4.

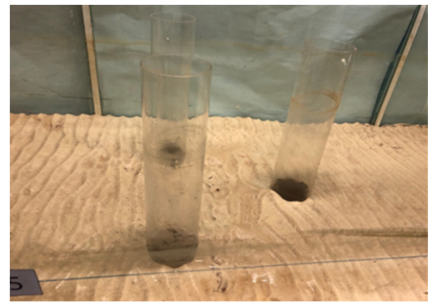

a) Wave

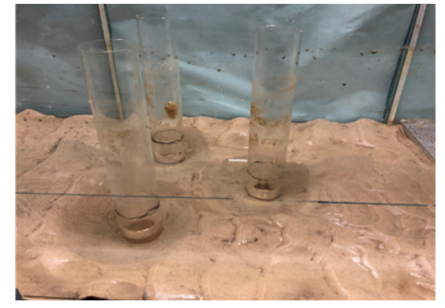

b) Current

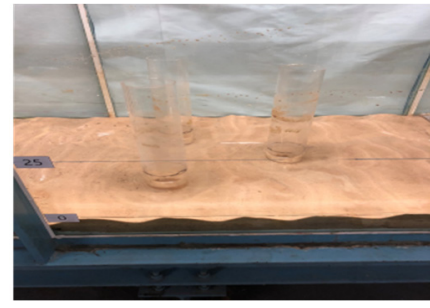

c) Current and wave

Fig. 5. Photo of 3 group piles experiment result

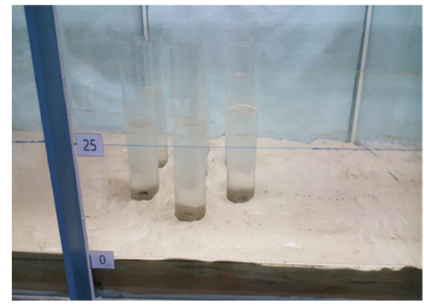

a) Wave

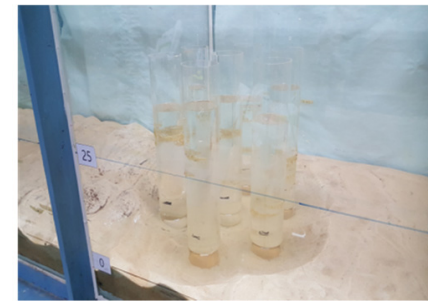

b) Current

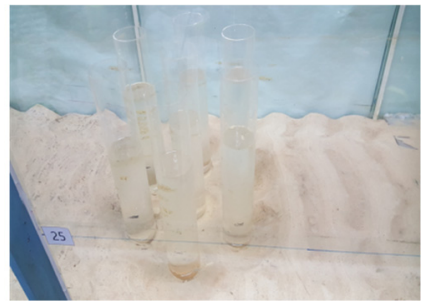

c) Current and wave

Fig. 6. Photo of 7 group piles experiment result

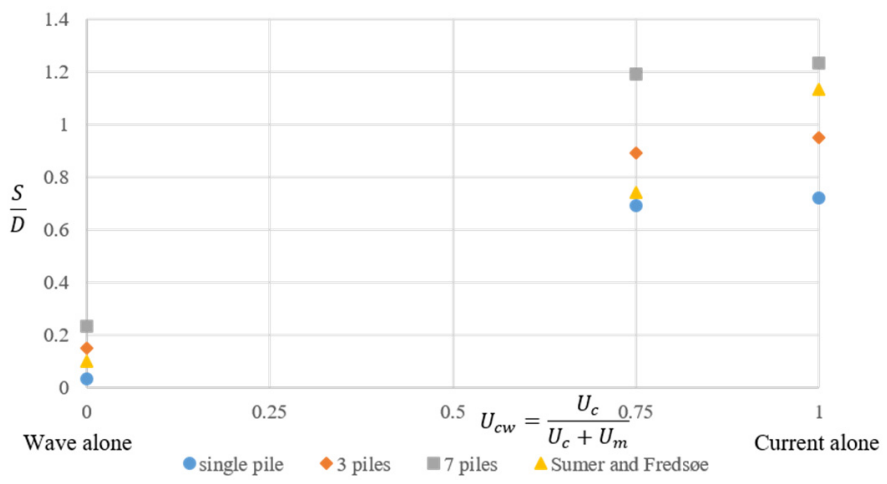

Fig. 7. Experimental scour depth and theoretical scour depth $(S / D)$ 
In cases of wave alone, $S / D$ was not much difference compared to result. Therefore, current cases and current and wave cases were compared. The Fig. 8(a), (b) are $S / D$ of Sumer and Fredsøe result and experimental result in current only flow and current and wave, see Fig. 8.

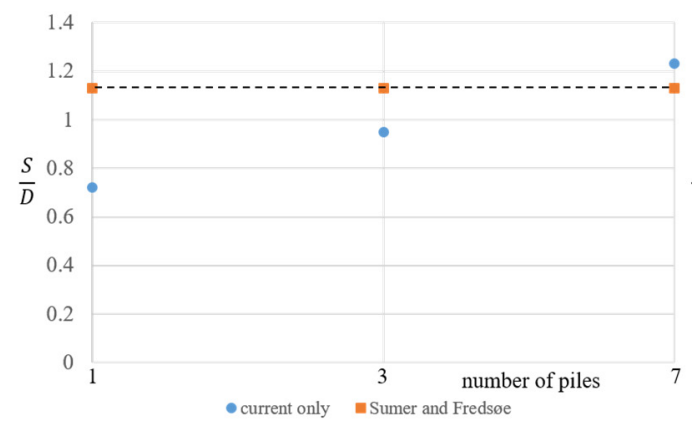

a) Current only

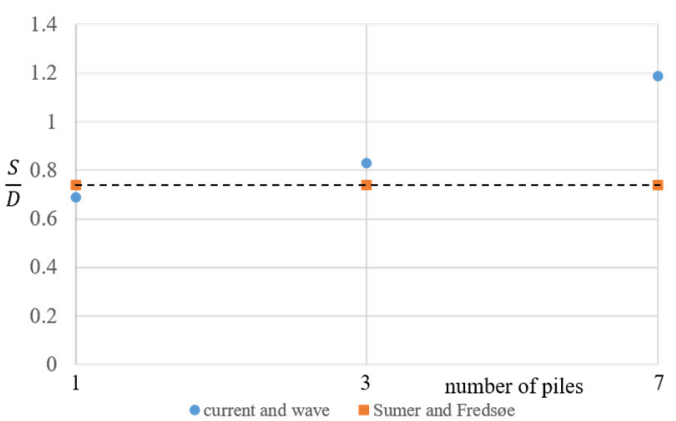

b) Current and wave

Fig. 8. Scour depth of according to number of piles

\section{Conclusions}

Experiment exhibited that the pile number increase the total scour depth, for the same gap over diameter ratio.

Experimental results demonstrate that the scour depths were small for wave only flows. Results also demonstrate that the scour depths for current and wave flows are slightly smaller or equal to those for current only flows. These results imply that the experimental conditions adopted include phases which may result in the sheer flow condition due to added reversing wave flows.

The conditions in the present experiments don't cover all field environment. However, it is hoped that the flow and sediment conditions of their experiment represent a typical environment of the west coast of Korea. Wider range of conditions are recommended for real field design purposes.

For single pile cases, the scour occurred just around pile. However, for group piles cases, scour developed deeper than single pile, and scour was wider. Moreover, the larger the number of piles, the deeper the total depth of scour.

\section{Acknowledgements}

This work has been funded as a Research Project, "Installation and Corroborative Study for Internal Power Network of Ocean Wind Power Plant", by Korea institute of Energy Technology Evaluation and Planning (KETEP) since 2015.

\section{References}

[1] Sumer B. M., Fredsøe J. Scour below pipelines in waves. Journal of Waterway, Port, Coastal, Ocean Engineering, ASCE, Vol. 116, Issue 3, 1990, p. 307-323.

[2] Sumer B. M., Fredsøe J., Christiansen N. Scour around vertical pile in waves. Journal of Waterway, Port, Coastal, Ocean Engineering, ASCE, Vol. 118, Issue 1, 1992, p. 15-31.

[3] Sumer B. M., Fredsøe J. Wave scour around group of vertical piles. Journal of Waterway, Port, Coastal, Ocean Engineering, ASCE, Vol. 124, Issue 5, 1998, p. 248-256.

[4] Sumer B. M., Fredsøe J. Scour around pile in combined waves and currents. Journal of Hydraulic Engineering, ASCE, Vol. 127, Issue 5, 2001, p. 403-411. 